\title{
Apple Economy of Village Zandra in Light of World System Theory
}

\author{
Anwaar Mohyuddin ${ }^{1 *}$, Hafeez-Ur-Rehman Chaudhry ${ }^{1}$, Mamonah Ambreen ${ }^{2}$ \\ ${ }^{1}$ Department of Anthropology, Quaid-i-Azam University, Islamabad, Pakistan \\ ${ }^{2}$ Department of Education, AllamaIqbal Open Univetsity, Islamabad, Pakistan \\ Email: *unwaar@gmail.com
}

Received November 28, 2012; revised December 29, 2012; accepted January 5, 2013

\begin{abstract}
This paper deals with research findings regarding horticulture, a major sources of income in the Village Zandra, District Ziarat in the province of Balochistan. Initially the natives were earning their livelihood through horticulture only. The main contribution was coming through apple production. The process of tree plantation and the people involved in horticulture economy have been discussed in this article. During the last 3 decades few changes have been witnessed. Shift from subsistence to market economy has increased the lust for money due to which the natives have started opting for secondary sources of income. In horticulture they have started using technology, pesticides and chemical fertilizers to maximize their production and profit. They are also switching over to the cultivation of profitable types of apple. The impact of these changes has been analyzed in light of world system theory at micro level. The data presented in this paper have been collected by using qualitative anthropological research techniques.
\end{abstract}

Keywords: Core; Periphery; Semi-Periphery; Capitalist Economies; Labour; Exploitation

\section{Introduction}

In 1915 Haji Payo Khan started cultivating apple in Zandra after being inspired by the lush green fields in Punjab. He worked day and night and made a model apple orchard, which eventually proved to be fruitful. Hence, the lives of the villagers changed by following his practices in the field in the years to come. Payo Khan, thus, not only turned the barren land into lush green orchards but also changed the fortune of the people of the village, who were initially semi-nomads. After this unprecedented work by Haji Payo Khan, they settled down permanently. In the past, the Pashtoon of this area were pastoral and used to grow few crops for their subsistence. Haji Payo Khan was the first educated person of Zandra. He was awarded with Sitara-e-Khidmat (award from Government of Pakistan) in horticulture for his revolutionary work. He died in 1970 at an age of 100 years. Haji Payo Khan, the founder of apple economy became mentally retarded in the last days of his life and was still known as "the mad-man of Zandra" and the village was known as "village of mad man".

\section{Research Methodology}

The present research was conducted in Village Zandra, District Ziarat, in Baluchistan, Pakistan. Zandra Village

${ }^{*}$ Corresponding author. is situated $108 \mathrm{~km}$ southeast of Quetta just $12 \mathrm{~km}$ short of Ziarat town. Qualitative anthropological research methods which include socio-economic survey, participant observation, key informant interviews and in-depth interviews were used to collect empirical data. Stratified random sampling based upon social classes was used for selecting 100 households. This research was a longitudinal study. First of all a 4 months visit was conducted in 1987, then a couple of month long visits in 1990s and finally in 2007.

\section{Theoratical Framework}

This research has been embedded in the theoretical discourse of world system theory commonly known as world systems analysis. The world system approach was developed by Immanuel Wallerstein in 1970s and 1980s. His three volume work "The modern world system" [1-3], and number of essays [4-8] were the major contribution in developing the theory. The other contributors of world system theory are Samir Amin [9,10], Cardoso and Falleto [11], Santos [12,13], Rodney [14], and Andre Gunder Frank [15,16].

Wallerstein has divided the capitalist system the world into different zones on the basis of their wealth and size which keeps on competing with one another for wealth and power. These zones are "core", "semi-peripheral" and "peripheral" regions. The core region includes the most 
powerful and technologically advanced countries. Periphery includes poorer and technologically less advanced countries. Economies of these countries mostly based upon the raw material export. The semi-periphery includes the countries which are poorer to the core but have the potential to take core status if the conditions suit them.

Core countries earn very high profits from international trade. They exchange manufactured products for raw materials mainly from peripheral countries and to some extent from the semi-peripheral countries. The core countries are becoming richer and richer at the cost of the peripheral economies. In general this theory says that the world's capitalist economies determine the rout for development of the large part of the world's population in their own favour.

Its geographic expansion has changed political systems as well as the labour conditions wherever it could penetrate. Functions of the world economy have created big differences and inequalities among the economies of different countries. The relationship between the core, peripheral and semi-peripheral countries are also relative inconstant. Technological development brings positive changes all over the world. Some impulsive changes are brought in peripheral or semi-peripheral countries, but the core countries get the most advantage. Wallerstein, however, after the analysis of history of the capitalist world system firmly concluded that this development has created inequality and disparities in economic and social sectors of different countries rather than bringing prosperity all over the world.

Most of the world system theorists have analyze its implementation at macro level. The exploitative relation between core and periphery has been studied at state level. In this research this model will be put on test at micro level to confirm, revise or drastically change the reasoning built into this. Its impact would be observed on village economy. The researchers would try to examine how this development of underdevelopment influences the masses at grass root level. Arnove [17] has emphasized the need of further research at micro level.

\section{Apple Economy}

According to 1998 census the total area of Zandra is 1229 acres; out of which 367 acres are under apple orchard. In 1986 the area under apple orchard was 227 acres. Reportedly, special efforts were made by the villagers at individual level to expand the area under fruit orchards. Apple is cultivated in all 367 acres of land. Some farmers have also planted other fruit trees in the same orchards i.e cherry, apricot, peaches and almonds etc. The ratio between apple and other fruits is 95\%:5\% respectively.
Since the middle of $20^{\text {th }}$ century, the village economy has undergone a transition. Initially it was based on horticulture only with apple as the main source of income, but over the years the population has outgrown the farming resources. Landholdings have reduced and hence the majority, apart from providing services to the orchards, during the season, has taken up other nonagricultural activities like different businesses and employment in public and private sector to earn additional income. In order to further supplement domestic income, the women folk have also started producing home based handicrafts like crochet work, embroidery, stitching etc. besides the household chores. Women are also working mostly as teachers and some others as lady health workers (LHWs), lady health visitors (LHVs) lady doctors etc. but they are very few in numbers.

In spite of these changes apple is still the main source of income for majority of the people in the village. The natives mostly depend upon the income from the orchards. Apple trees bear fruit only once a year during April-August. Thus, the people, who solely depend on the apple production can only earn once a year. The big landholders can easily spend whole year on the orchard income. An average annual income per acre is Rs. 300,000 to 400,000 .

\section{Process of Horticulture}

The steps involved in horticulture are production, plucking, packing and sale. In Zandra, there are three types of land i.e land prepared by flood water, plain land and stony land. Plain land is artificially prepared by leveling the stony land with the help of bulldozer and filling it up with mud brought from the dam. After leveling trees are planted in March or December because more water is available as the schedule of Karez is suspended and anybody can use it. For better production of fruit, grafting and budding of trees is done in two different ways which include “Tee Budding” and "Ring Budding”. Fertilizers and insecticides are also used whenever needed.

An apple tree takes about seven years to grow, but their production remains low. The trees ageing ten to fifteen years give maximum and a very high quality production. After that the quality starts deteriorating because the trees get thicker and the proper amount of sunlight does not reach the fruit and it starts losing its colour.

Since the start of apple economy 9 different kinds of apple were grown in the orchards, which includes Kala Kolu (Tor Kolu), Sabaz Kolu (Shin Kolu), Lal Kolu, Kashmiri, Mashadi, Ameri, Kandhari, American and Fransi. Kala Kolu is considered to be the best and dearest of all apples. It is also called Golden apple. Sabaz Kolu has a longer life. It can be stored for longer durations. As far as the taste is concerned, both of these are considered 
as the best. Kashmiri, Mashadi, Ameri and Kandhari come in the next order of taste and quality. American, Fransi and Lal Kolu are small in size and sour in taste, and are used for making jams and juices only.

But now from the last 20 years, the people have gradually switched over to two kinds of apple-Kala Kolu and Gaja, because of their great export value and local market demand. Both of these types have higher rates and bring them more profit. This shows that desire for more money is forcing them to abandon their traditions. This traditional society is gradually changing into a more profit oriented society.

\section{Use of Technology}

During the last couple of decades technology has played a pivotal role in the development of new cultivation methodologies. Beasts of burden such as donkeys and bulls are no longer used for cultivation; instead tractors and bulldozers are used. Modern spraying machines for insecticide, trucks for transportation and chemical fertilizers are commonly used. Office of Agriculture Department in the village creates awareness and facilitates the natives to use modern technology. Improved road network has made market access easier. Until 2002 horticulture production was mainly depending on Karez water. A small area was irrigated through tractorpowered wells. In 2002 electric tube-wells were introduced in the area. These tube-wells are providing sufficient amount of water and fulfilling most of their irrigational needs.

\section{People Related to Apple Economy}

There are many individuals in the village who are in one way or the other involved in production, distribution and sale of apple. Apple economy of the village is based on a complete cycle of individual efforts that are related to apple economy for their earnings. Their role in the apple economy and how they are organized is explained as under.

\subsection{Owner of the Orchard}

The horticulturalists of the village could be divided into three categories which include owner cultivators who work in their fields and market their product themselves. Majority of the medium and small landholders falls under this category. Exporters normally approach the owners themselves. The direct access of the exporters to the farms is a new phenomenon, which has become popular during two decades. Now more than $40 \%$ of the total apple production is sold to them. The second category is owner non-cultivators. Big as well as small landholders who do not work in their orchards fall under this category. Non-owners cultivators are the third category which includes landless and the small landholders. They hire the orchard in the beginning under a contract, work there and in the end share half of the produce with the owner.

\subsection{Local Contractors}

Local Contractor is the person who purchases the whole lot of apples from the owner under an agreement and sells it in the market. The contractors from different areas visit the village and make the agreements well in time before the apples ripe normally in July and August. Contractors give offers to the owners after assessing the quality and quantity of the apple. They normally offer $65 \%-70 \%$ of the expected market value of the apple. If the deal finalizes the contractor pays the first installment and takes all responsibility like taking care of the orchard, spraying pesticides, plucking, packing and transporting of apples. The responsibility of irrigation stays with the owner.

\subsection{Contractor in Fruit Market}

These contractors have their offices in different fruit markets such as Lahore, Karachi, Multan, Hyderabad and Faisalabad. They make high level deals for purchasing the fruit. The local contractors work in the village normally work on their behalf. They pay them partial amounts in advance before the start of the season and bound them to bring a specific quantity of apple in the end of the season. The arti recovers his investment, along with $5 \%$ commission or service charges.

\subsection{Labour}

Some labour is also required during the production season to work in the fields which includes watchmen who take care of the orchard throughout the season, people who pluck the fruit when it ripe, experts who categorizes the fruit according to it quality, box makers, packers, and the markers who write on the boxes after being packed,

\subsection{Transporters}

The transporters do not belong to the village. In the apple production season i.e. in August to September there are numberless trucks available here. After selling the export quality to the exporter they take rest of the fruit to different fruit markets in Faisalabad, Lahore, Multan, Karachi and other cities where it is sold to the artis (contractors in fruit market).

\section{Effects of Apple Economy}

Since the advent of apple economy, the Pashtoons have gone through a social and economic change. Due to their interactions with the people in different markets they have become aware of their surroundings and technolo 
gy, which they are utilizing to achieve their horticultural goals. They have become more settled and economically better-off today. There is a complete shift from lower to middle class because of this apple economy. Haji Payo Khan started growing apple in early $20^{\text {th }}$ century. Later the natives accepted the idea and followed him. Today majority of the villagers enjoy basic facilities. Now many of them have their own cars, property and running businesses in Quetta.

\section{Theoretical Analysis}

In the beginning of $20^{\text {th }}$ century people of the village were nomads, apple economy brought them to permanent settlements. Subsistence economy has changed into market economy. Farmers started growing fruits and crops to sell in the market. Their reliance on consumer products increased. Shift from subsistence economy to market economy supports the industry as the raw materials, which includes livestock and farm production are sold in the market to earn money and for personal consumption they are bought from the market produced or processed by the industry. So the ultimate beneficiary of this change remains the industrialist of core countries for being producer of all these products.

Since the middle of $20^{\text {th }}$ century, the village economy was based on horticulture with apple as the main source of income, but now they are involved in different businesses and employment in public and private sector to earn additional income. In order to further supplement domestic income, the women have started working. Some of them have started producing home based handicrafts. Moving from horticulture economy to businesses and employments in public and private sector to earn additional income also benefits the industry as it finds cheap labour. Supplementary domestic income by the women folk through handicrafts helps to maintain low wage rates.

Joint families are breaking into nuclear families, which has changed the bigger land holding patterns to the small pieces of land. When joint families break into nuclear families it normally results into urban migration where the majority of the adults work for the industry and their dependence upon the consumer products also increases.

In the field of horticulture use of technology, modern techniques, transportation, pesticides and chemical fertilizers is clearly visible and it has grown during the last three decades. All these items are imported from the core countries sometimes in shape of finished products and sometimes in shape of instillations, industrial supplies and fabricated parts. Use of pesticides and chemical fertilizers gives rise to health problems due to which medical bill increases and the pharmaceutical industry of the core countries gets benefit. The transfer of wealth by exploiting periphery and semi-periphery by core countries which encourages rapid scientific development so that Western medicine and other scientific institutions could surpass underdeveloped countries of the world.

The low profit farm products are no more cultivated. Majority of the natives has switched over to the types having great export value, local market demand and high profit. The market is in transition from local market to the export. Before $1980 \mathrm{~s}$ total production was consumed at local markets but now more than $40 \%$ of the apple is sold to the exporters. Increase in the export of farm products supports Wallerstein argument where he says that world is becoming a single economic unit through exchange and trade with a vast diversity in division of labour among the countries.

In the end the researcher is in full agreement with the views of world system theorists who have been working in the field of capitalist world economy. The argument developed by Wallerstein, Samir Amin, Cardoso and Falleto, Santos, Rodney, and Andre Gunder Frank seems valid. So in the light of empirical data world system theory is found valid and accepted.

\section{Conclusion}

This Industrial Revolution brought some significant change in man's life. The concept of development changed from enhancement of the richness of human life to the richness of the economy in which a man lives. This change has also affected the natives' life and village economy. The village has gone through some major structural changes during recent past. The natives are economically well off which they consider as development. This development has increased their choices. Use of technology, pesticides and chemical fertilizers have become common ignoring all environmental issues and health hazards. The natives are happy as far as cash flow increases which result in the growth of per-capita income and increase in the volume of consumer goods and thus improve the material quality of life of the people. On the other hand it has also resulted into the disintegration of social bonds in the village. This situation supports the world's capitalist economies in different ways. Technology, pesticides, chemical fertilizers pharmaceutical and consumer products are imported from core countries which in turn promotes growth for capitalist industry on one side and increases lust for money among the natives on the other who start selling their services and raw materials to the industry to fulfill their economic needs. So interdependence exists, for periphery it is for finished products and for core it is for raw materials and human resource. This interdependence supports the core countries as the consumer products used in peripheral countries become a source of profit and inexpensive raw 
material and cheap labour provide them savings. So they are becoming richer and richer at the cost of the peripheral economies.

\section{REFERENCES}

[1] I. Wallerstein, “The Modern World System, Vol. I: Capitalist Agriculture and the Origins of the European World Economy in the Sixteenth Century," Academic Press, New York, 1974.

[2] I. Wallerstein, “The Modern World System II: Mercantilism and the Consolidation of the European World Economy, 1600-1750,” Academic Press, New York, 1980.

[3] I. Wallerstein, "The Modern World System, Vol. III: The Second Great Expansion of the Capitalist World Economy 1730s-1840s,” Academic Press, San Diego, 1989.

[4] I. Wallerstein, "The Rise and Future Demise of the World Capitalist System: Concepts for Comparative Analysis,” Comparative Studies in Society and History, Vol. 16, No. 4, 1974, pp. 387-415. doi:10.1017/S0010417500007520

[5] I. Wallerstein, "The Capitalist World Economy," Cambridge University Press, New York, 1979.

[6] I. Wallerstein, "Nationalism and the World Transition to Socialism: Is There a Crisis?” Third World Quarterly, Vol. 5, No. 1, 1983, pp. 95-102. doi:10.1080/01436598308419681

[7] I. Wallerstein, "The Rise and Future Demise of World Systems Analysis," 91st Annual Meeting of the American Sociological Association, New York, 16 August 1997, pp. 1-8.
[8] I. Wallerstein, "World-Systems Analysis, in World System History,” In: G. Modelski, Ed., Encyclopedia of Life Support Systems (EOLSS), UNESCO. Eolss Publishers, Oxford, 2004, pp. 1-14.

http://www.eolss.net/ebooks/Sample\%20Chapters/C04/E 6-94-01.pdf

[9] S. Amin, "L’accumulation à L'échellemondiale; Critique de la Théorie du Sous-Développement,” IFAN, Dakar, 1970.

[10] S. Amin, “Neo-Colonialism in West Africa,” Penguin, Hamondsworth, 1973.

[11] F. H. Cardoso and E. Falletto, "Dependenciay Desarollo en América Latina,” Siglo Ventiuno, Mexico City, 1969.

[12] T. Dos Santos, "Dependenciaeconómicay Cambiorevolucionario,” Nueva Izquierda, Caracas, 1970a.

[13] T. Dos Santos, “The Structure of Dependency," American Economic Review, Vol. 60, No. 2, 1970b, pp. 231-236.

[14] W. Rodney, "How Europe Underdeveloped Africa," Howard University Press, Washington, 1974.

[15] G. Frank, "Capitalism and Underdevelopment in Latin America,” Monthly Review Press, New York, 1969.

[16] A. G. Frank, "No Escape from the Laws of World Economics," Review of African Political Economy, Vol. 18, No. 50, 1991, pp. 21-32. doi:10.1080/03056249108703885

[17] R. F. Arnove, "Comparative Education and World-Systems: Comparative,” Education Review, Vol. 24, No. 1, 1980, pp. 48-62. 